Marek KICZEK ${ }^{1}$, Maciej POMPA-ROBORZYŃSKI ${ }^{2}$

\title{
OCENA ROZWOJU GMIN POWIATU RZESZOWSKIEGO (Z WYKORZYSTANIEM METODY HELLWIGA)
}

\begin{abstract}
W opracowaniu podjęto problematykę rozwoju lokalnego i czynników rozwój ten warunkujących. Głównym celem opracowania jest określenie poziomu rozwoju społecznogospodarczego gmin powiatu rzeszowskiego ziemskiego. Metodą zastosowaną w pracy jest syntetyczny miernik rozwoju Hellwiga. Miernik ten uwzględnia szereg wskaźników o charakterze ekonomicznym, społecznym, technicznym i technologicznym oraz ekologicznym. Wśród nich wskazać należy na: wskaźnik przyrostu naturalnego, odsetek pracujących w liczbie ludności ogółem, saldo migracji w osobach na 1000 mieszkańców, udział bezrobotnych w liczbie ludności w wieku produkcyjnym, drogi gminne o twardej nawierzchni $\mathrm{w} \mathrm{km}$ w przeliczeniu na $100 \mathrm{~km}^{2}$, sieć wodociagowa w $\mathrm{km}$ w przeliczeniu na $100 \mathrm{~km}^{2}$, sieć kanalizacyjna w $\mathrm{km} \mathrm{w}$ przeliczeniu na $100 \mathrm{~km}^{2}$, udział procentowy ludności korzystającej z oczyszczalni ścieków w ludności ogółem, dochody własne gmin w przeliczeniu na 1 mieszkańca, wydatki majątkowe inwestycyjne gmin w przeliczeniu na 1 mieszkańca, podmioty gospodarcze prywatne zarejestrowane w REGON w przeliczeniu na 1000 mieszkańców, odsetek radnych z wyższym wykształceniem. Badania mają charakter statyczny a zgromadzone dane empiryczne przedstawiają stan na dzień 31 grudnia $2011 \mathrm{r}$. W przeprowadzonych badaniach wykazano znaczne zróżnicowanie w poziomie rozwoju analizowanych gmin. Za główne czynniki rozwoju uznano bliskość ośrodka centralnego, jakim jest Rzeszów, oraz skomunikowanie gmin. Nie bez znaczenia jest również zróżnicowanie $\mathrm{w}$ potencjale rozwojowym gmin wynikające chociażby $\mathrm{z}$ ukształtowania terenu. W świetle przeprowadzonych badań stwierdzono, że najlepiej rozwiniętymi gminami powiatu rzeszowskiego ziemskiego są gminy Boguchwała i Tyczyn, zaś najsłabiej rozwinięta jest gmina wiejska Dynów.
\end{abstract}

Słowa kluczowe: rozwój lokalny, metoda Hellwiga, powiat rzeszowski ziemski

\section{WPROWADZENIE}

Rozwój lokalny jest pojęciem wielowymiarowym i postrzegany jest jako zmiany ilościowe $\mathrm{i}$ jakościowe zachodzące $\mathrm{w}$ społecznym i gospodarczym funkcjonowaniu jednostek samorządu terytorialnego ${ }^{3}$. Czynniki determinujące ten proces mają złożony charakter i siłę oddziaływania. Rozwój lokalny oznacza długotrwały proces kierunkowych zmian, w którym można wyróżnić prawidłowo po sobie następujące etapy przemian

\footnotetext{
${ }^{1}$ Dr inż. Marek Kiczek, Wydział Zarządzania, Katedra Ekonomii, Politechnika Rzeszowska, al. Powstańców Warszawy 10, 35-959 Rzeszów, tel. 17865 1403, autor korespondencyjny: mkiczek@prz.edu.pl

${ }^{2}$ Prof. dr hab. inż. Maciej Pompa-Roborzyński, Wydział Zarządzania, Katedra Prawa i Administracji, al. Powstańców Warszawy 10, 35-959 Rzeszów, Politechnika Rzeszowska. ${ }^{3}$ T. Markowski, Teoretyczne podstawy rozwoju lokalnego i regionalnego, [w:], Gospodarka regionalna i lokalna, red. Z. Strzelecki, Warszawa 2008, s. 9.
} 
danego obiektu. Można także powiedzieć, że jest procesem kierunkowych przemian, w którego toku dochodzi do przejścia od form lub stanów prostszych i mniej doskonałych do stanów bardziej złożonych i doskonalszych pod określonymi względami ${ }^{4}$. Analizując zjawisko rozwoju lokalnego, nie sposób uniknąć przestrzennego kontekstu omawianego procesu. Czynnik przestrzeni geograficznej niejednokrotnie ma kluczowe znaczenie w kształtowaniu charakteru, skali i dynamiki rozwoju ${ }^{5}$. Zasadniczo czynniki rozwoju lokalnego można podzielić, za Wojciechem Kosiedowskim ${ }^{6}$, na cztery podstawowe grupy: 1. ekonomiczne,

2. społeczne,

3. techniczne i technologiczne,

4. ekologiczne.

W grupie czynników ekonomicznych istotną rolę odgrywają: wielkość i sposób funkcjonowania lokalnego rynku dóbr i usług, zmiany na lokalnym rynku pracy, zmiany dochodów ludności, przedsiębiorstw i organów samorządu, napływ inwestycji krajowych i zagranicznych. Wskazać również należy na rolę wzrostu przedsiębiorczości i innowacyjności, jakość marketingu lokalnego czy poziom zarządzania. Na sytuację ekonomiczną w wymiarze lokalnym wpływają również czynniki zewnętrzne, takie jak sytuacja makroekonomiczna kraju czy koniunktura na rynku europejskim i światowym.

Wśród czynników społecznych do najważniejszych trzeba zaliczyć zmiany w liczbie ludności i strukturze demograficznej, tempo i charakter procesów urbanizacji, aglomeracji i metropolizacji. Ponadto istotną rolę odgrywają również: rozwój i doskonalenie infrastruktury społecznej, zmiany w poziomie i stylu życia, poprawa wykształcenia, aktywność i zaangażowanie zarówno władz, jak i społeczności lokalnej, poprawa dostępu do kultury oraz wzrost jej jakości, sprawność funkcjonowania władzy lokalnej, partycypacja społeczeństwa w podejmowaniu lokalnych decyzji.

Grupę czynników technicznych i technologicznych stanowią: ilość i jakość kapitału trwałego i zmiany w jego strukturze, wzrost udziału produktów wysoko przetworzonych wykonanych w oparciu na wysokich technologiach, rozwój działalności badawczorozwojowej, zacieśnianie współpracy sektora nauki z przemysłem, dywersyfikacja produkcji, poprawa konkurencyjności technicznej produkcji, rozwój i doskonalenie infrastruktury technicznej, przygotowanie terenów pod inwestycje.

Ekologicznych aspektów rozwoju lokalnego należy upatrywać w dostępie do zasobów naturalnych, racjonalizacji gospodarowania zasobami środowiska przyrodniczego, wdrażaniu „czystych” technologii, stymulowaniu produkcji zdrowej żywności, poprawie świadomości i kultury ekologicznej społeczeństwa, postępie w edukacji ekologicznej, wdrażaniu nowoczesnych instrumentów ochrony środowiska.

Wymienione czynniki zwykle oddziałują na procesy rozwojowe w sposób łączny, stanowiąc wiązkę determinant rozwoju. Często dochodzi do sprzężenia pomiędzy poszczególnymi czynnikami. Zagadnienie rozwoju lokalnego należy zatem rozpatrywać kompleksowo, mając świadomość, że wiele procesów ma charakter przyczynowoskutkowy. Przyczyny i skutki są ze sobą nawzajem powiązane i łączą się ze wszystkimi

\footnotetext{
${ }^{4}$ Nowa encyklopedia powszechna, PWN, Warszawa 1997, s. 616.

${ }^{5}$ M. Ziółkowski, M. Goleń, Zarzqdzanie strategiczne rozwojem lokalnym, [w:] Zarzqdzanie gospodarkq i finansami gmin, red. H. Suchocka-Krysiak, Warszawa 2003, s. 43.

${ }^{6}$ W. Kosiedowski, Zarzqdzanie rozwojem regionalnym $i$ lokalnym, [w:]:Gospodarka regionalna $i$ lokalna, red. Z. Strzelecki, PWN, Warszawa 2008, s. 232.
} 
wymienionymi aspektami rozwoju. Mogą one stanowić czynniki rozwoju lokalnego, choć mogą też ten rozwój hamować ${ }^{7}$.

\section{CHARAKTERYSTYKA OBIEKTU BADAŃ}

Powiat rzeszowski to 14 gmin położonych wokół miasta wojewódzkiego Rzeszowa (jedna miejska, pięć miejsko-wiejskich oraz osiem wiejskich). Zajmuje powierzchnię $1157 \mathrm{~km}^{2}$, a zamieszkuje go przeszło 160 tys. osób. Położony jest w centrum Podkarpacia. Powiat rzeszowski ma stosunkowo dobrze rozwiniętą infrastrukturę techniczną i dogodną sieć dróg. W położonej nieopodal Rzeszowa Jasionce, usytuowane jest lotnisko przystosowane do regularnej obsługi międzynarodowego ruchu pasażerskiego i towarowego. Port ten dysponuje najnowszą i jedną $\mathrm{z}$ najdłuższych $\mathrm{w}$ Polsce drogą startową umożliwiającą przyjmowanie każdego typu samolotu.

Charakterystyczną cechą powiatu rzeszowskiego, jak również Polski południowowschodniej, jest mocne zakorzenienie przemysłu lotniczego. W Jasionce funkcjonuje także Ośrodek Kształcenia Lotniczego Politechniki Rzeszowskiej.

Powiat rzeszowski jest miejscem, które oferuje coraz lepsze warunki do podejmowania działalności gospodarczej, zamieszkania, pracy, a także do uprawiania różnych form turystyki. Liczba mieszkańców w powiecie rzeszowskim w ostatnich latach stale rośnie. W 2009 r. saldo migracji na 1000 osób wynosiło $+5,4$ przy wskaźniku $-0,9$ dla województwa podkarpackiego. Miejscowości powiatu rzeszowskiego charakteryzuje także rozwój budownictwa oraz różnorodność podejmowanych inicjatyw i przedsięwzięć gospodarczych.

Pozytywnym zjawiskiem jest dynamiczny wzrost liczby podmiotów gospodarczych. Pod tym względem powiat rzeszowski przewyższa jedynie stolica województwa podkarpackiego, czyli miasto Rzeszów. Na koniec 2012 r. w powiecie rzeszowskim funkcjonowało ponad 10300 podmiotów gospodarki narodowej zarejestrowanych $\mathrm{w}$ rejestrze REGON. Od wielu lat prężnie rozwija się produkcja bazująca na lokalnych tradycjach oraz zasobach naturalnych, na przykład wikliniarstwo, produkcja zdrowej żywności i wody mineralnej. Rolnictwo powiatu, podobnie jak całego województwa podkarpackiego, dostarcza żywność znacznie czystszą ekologicznie niż inne regiony Polski.

O atrakcyjności inwestycyjnej powiatu rzeszowskiego decydują także inwestycje realizowane $\mathrm{W}$ otoczeniu lotniska. Znajdujący się tu Podkarpacki Park NaukowoTechnologiczny AEROPOLIS jest jednym $\mathrm{z}$ najatrakcyjniejszych miejsc lokowania inwestycji w południowo-wschodniej Polsce. Przyciaga on nowoczesne firmy i technologie. Wykorzystywany jest tu również potencjał miejscowych uczelni wyższych i ośrodków naukowo-badawczych. Na uwagę zasługują podstrefy Specjalnej Strefy Ekonomicznej EURO-PARK MIELEC, a także grunty wyróżnione w konkursie „Grunt na medal". Rozwojowi gospodarczemu tego terenu ma służyć projekt dotyczący wyposażenia w odpowiednią infrastrukturę techniczną terenów inwestycyjnych w miejscowościach: Przybyszówka, Miłocin i Pogwizdów Nowy.

Władze powiatu, jak też samorządy tworzących go gmin konsekwentnie, za pomocą między innymi środków unijnych, realizują inwestycje mające na celu poprawę

\footnotetext{
${ }^{7}$ Ibidem.
} 
warunków życia tutejszych mieszkańców. Pomagają im w tym liczne organizacje pozarządowe oraz lokalni liderzy.

Czyste, nieskażone powietrze, niepowtarzalne krajobrazy, ciekawa kultura ludowa, dobre warunki do uprawiania turystyki aktywnej, liczne zabytki oraz podania i legendy z nimi związane sprawiają, że powiat rzeszowski jest także doskonałym miejscem do weekendowego i urlopowego wypoczynku. Powiat rzeszowski oferuje ciekawe wędrówki, a także podróż kolejką wąskotorową Przeworsk-Dynów z najdłuższym w Europie, bo liczącym 602 m tunelem kolei wąskotorowej w Szklarach. W Sołonce, bazując na studni solankowej z 1596 roku, utworzono kaskadę solną o charakterze zdrojowym. Dzięki wspomnianym inwestycjom umożliwiono oddychanie powietrzem nasyconym jodem. Urządzenia wydobywcze i pozostałości dawnej studni, jako jedyne obiekty tego typu na Podkarpaciu, są eksponowane w Muzeum Regionalnym w Sołonce.

Z ziemiami, które obecnie należą do powiatu, związani byli wybitni Polacy. Należą do nich między innymi Jerzy z Tyczyna - poeta, humanista doby Oświecenia, sekretarz królów Zygmunta Augusta i Stefana Batorego, Władysław Sikorski - Naczelny Wódz Wojska Polskiego, premier na emigracji, Franciszek Kotula - znany rzeszowski etnograf, Jan Bolesław Ożóg - poeta, prozaik i publicysta.

Od kilku lat zachodzi proces poszerzania terytorium Rzeszowa o sołectwa będące w granicach gmin powiatu rzeszowskiego. W $2006 \mathrm{r}$. powiat zmniejszył się o $14,36 \mathrm{~km}^{2}$. Do Rzeszowa została przyłączona Słocina i Załęże. W 2007 r. odłączono od powiatu cześć Przybyszówki o powierzchni 9,25 $\mathrm{km}^{2}$, w 2008 r. zaś - pozostałą część tego sołectwa, czyli 7,01 $\mathrm{km}^{2}$, oraz Zwięczyce $\left(7,23 \mathrm{~km}^{2}\right)$. Rok 2009 to pomniejszenie powierzchni powiatu o Białą $\left(6,06 \mathrm{~km}^{2}\right)$, a 2010 - o Budziwój i część Miłocina (łącznie 18,77 km²). Mimo tego uszczuplania terytorium powiatu rzeszowskiego pod względem powierzchni wśród innych polskich powiatów plasuje się na 95. miejscu. Pod względem ludności znalazł się zaś na czternastej pozycji ${ }^{8}$.

\section{METODA BADAŃ}

Badaniem objęto gminy powiatu rzeszowskiego ziemskiego. Dane do konstrukcji wskaźnika rozwoju społeczno-gospodarczego pobrano głównie $\mathrm{z}$ Banku Danych Regionalnych Głównego Urzędu Statystycznego (BDR GUS), które dotyczyły roku 2011.

Wstępny etap prac nad doborem zmiennych dla wskaźnika rozwoju gmin polegał na studiach literatury dotyczącej problematyki pomiaru poziomu rozwoju jednostek samorządu terytorialnego ${ }^{9}$. Jako że wybrane zmienne dotyczą konkretnego momentu (31 grudnia 2011 r.), dlatego należy zaznaczyć, że przeprowadzone badania mają charakter statyczny. Niemniej jednak dokonane analizy umożliwiają szeregowanie (tworzenie rankingu) badanych jednostek terytorialnych $\mathrm{w}$ danym okresie $\mathrm{w}$ zakresie poziomu ich rozwoju.

Do budowy wskaźnika rozwoju gmin przyjęto zmienne diagnostyczne o charakterze mierzalnym, dostępne i kompletne. Należy zwrócić uwagę, że w trakcie gromadzenia materiału empirycznego nastąpiła konieczność odrzucenia potencjalnie istotnych

\footnotetext{
${ }^{8} \mathrm{http}: / /$ www.powiat.rzeszow.pl/ (dostęp: kwiecień 2013).

${ }^{9}$ Taksonomiczna analiza przestrzennego zróżnicowania poziomu życia w Polsce $w$ ujęciu dynamicznym, red. A. Zeliaś, Wydawnictwo Akademii Ekonomicznej w Krakowie, Kraków 2000.
} 
merytorycznie zmiennych z powodu braku ich gromadzenia w BDL w układzie gminnym (na poziomie NTS 5).

Początkowym etapem analizy była eliminacja zmiennych quasi-stałych. Eliminacji tej dokonano, wykorzystując współczynnik zmienności cech. Dla każdej j-tej zmiennej obliczono współczynnik zmienności, który jest względną miarą rozproszenia, której wartość wyznaczana jest jako stosunek odchylenia standardowego do wartości średniej arytmetycznej zgodnie ze wzorem ${ }^{10}$ :

$$
V_{j}=\frac{S_{j}}{\bar{x}_{j}}
$$

gdzie:

$\mathrm{Vj}$ - współczynnik zmienności dla j-tej zmiennej,

$\mathrm{S}(\mathrm{xj})$ - odchylenie standardowe dla j-tej zmiennej, wyznaczane według wzoru:

$$
S_{j}=\sqrt{n^{-1} \sum_{i=1}^{n}\left(x_{i j}-\bar{x}_{j}\right)^{2}}
$$

$\mathrm{x}$ - średnia arytmetyczna $\mathrm{j}$-tej zmiennej, wyznaczana według wzoru:

$$
\bar{x}_{j}=n^{-1} \sum_{i=1}^{n} x_{i j} \quad(i=1,2, \ldots, n)
$$

Ze zbioru zmiennych eliminuje się cechy spełniające nierówność $|\mathrm{Vj}|<\mathrm{V}^{*}$, gdzie $\mathrm{V}^{*}$ oznacza wartość krytyczną współczynnika zmienności. Jako wartość krytyczną przyjęto $\mathrm{V}^{*}=0,10$. Ze względu na niską zmienność wyeliminowano cechę odsetek ludności w wieku produkcyjnym.

Następnie zbadano siłę związku między pozostałymi zmiennymi. W tym celu wykorzystano współczynnik korelacji liniowej Pearsona. Współczynnik ten służy do badania siły związku między zmiennymi wyrażonymi w wartościach nominalnych $\mathrm{i}$ przyjmuje następujący wzór ${ }^{11}$ :

$$
r_{x y}=\frac{\sum_{i=1}^{n}\left(x_{i}-\bar{x}\right)\left(y_{i}-\bar{y}\right)}{\sqrt{\sum_{i=1}^{n}\left(x_{i}-\bar{x}\right)^{2} \sum_{i=1}^{n}\left(y_{i}-\bar{y}\right)^{2}}}
$$

gdzie: $\mathrm{r}_{\mathrm{xy}}$ - współczynnik korelacji liniowej Pearsona; $\mathrm{X}, \mathrm{Y}$ - mierzalne cechy statystyczne; $\mathrm{X}=(1,2, \ldots, \mathrm{n}), \mathrm{Y}=(1,2, \ldots, \mathrm{n}) ; \mathrm{x}, \mathrm{y}-$ średnia arytmetyczna odpowiednio cechy X i Y. Współczynnik korelacji liniowej Pearsona przyjmuje wartości $\langle-1 ; 1\rangle$, przy czym: $\mathrm{r}_{\mathrm{xy}}=0$ oznacza brak liniowej zależności pomiędzy cechami, $\mathrm{r}_{\mathrm{xy}}=1$ oznacza dokładną dodatnią liniową zależność między cechami, a $\mathrm{r}_{\mathrm{xy}}=-1$ oznacza dokładną ujemną liniową zależność między cechami. Cechy, które wykazują silną współzależność, nie są uwzględniane w dalszych badaniach. Dla wszystkich zmiennych skonstruowano macierz korelacji. Jako wartość krytyczną współczynnika korelacji przyjęto $r^{*}=|0,75|$. Ze względu na wysoki stopień korelacji z pozostałymi zmiennymi wyeliminowano zmienne: udział dochodów własnych w dochodach ogółem oraz udział wydatków majątkowych inwestycyjnych w wydatkach ogółem. W rezultacie analiz otrzymano zbiór 17 zmiennych (tab. 1).

\footnotetext{
${ }^{10}$ B. Borkowski, H. Dudek, W. Szczęsny, Ekonometria, wybrane zagadnienia, Wydawnictwo Naukowe PWN, Warszawa 2004.

${ }^{11}$ W. Starzyńska, Statystyka praktyczna, Wydawnictwo Naukowe PWN, Warszawa 2005.
} 
Tabela 1. Zmienne diagnostyczne przyjęte w badaniach

\begin{tabular}{|l|l|}
\hline Symbol & Zmienna diagnostyczna \\
\hline$X_{1}$ & Wskaźnik przyrostu naturalnego \\
\hline$X_{2}$ & Odsetek pracujących w liczbie ludności ogółem \\
\hline$X_{3}$ & Saldo migracji w osobach na 1000 mieszkańców \\
\hline$X_{4}$ & Udział bezrobotnych w liczbie ludności w wieku produkcyjnym \\
\hline$X_{5}$ & Drogi gminne o twardej nawierzchni w km w przeliczeniu na $100 \mathrm{~km}^{2}$ w $2004 \mathrm{r}$. \\
\hline$X_{6}$ & Sieć wodociagowa w km w przeliczeniu na $100 \mathrm{~km}^{2}$ \\
\hline$X_{7}$ & Sieć kanalizacyjna w km w przeliczeniu na $100 \mathrm{~km}^{2}$ \\
\hline$X_{8}$ & Udział procentowy ludności korzystającej z oczyszczalni ścieków w ludności ogółem \\
\hline$X_{9}$ & Liczba ludności w przeliczeniu na 1 placówkę biblioteczną \\
\hline$X_{10}$ & Liczba korzystających z noclegów w obiektach zbiorowego zakwaterowania \\
\hline$X_{11}$ & Dochody własne gmin w przeliczeniu na 1 mieszkańca \\
\hline$X_{12}$ & Wydatki majątkowe inwestycyjne gmin w przeliczeniu na 1 mieszkańca \\
\hline$X_{13}$ & Udział procentowy obszarów chronionych w powierzchni gminy \\
\hline$X_{14}$ & $\begin{array}{l}\text { Podmioty gospodarcze prywatne zarejestrowane w REGON w przeliczeniu na } 1000 \\
\text { mieszkańców }\end{array}$ \\
\hline$X_{15}$ & Frekwencja wyborcza w wyborach do Sejmu RP w $2011 \mathrm{r}$. \\
\hline$X_{16}$ & Odsetek radnych z wyższym wykształceniem \\
\hline$X_{17}$ & Odsetek radnych o wysokich kwalifikacjach \\
\hline
\end{tabular}

Źródło: opracowanie własne.

Otrzymane zmienne umożliwiły podział gmin na trzy klasy różniące się pod względem poziomu rozwoju społeczno-gospodarczego, przy zastosowaniu taksonomicznego miernika rozwoju Hellwiga ${ }^{12}$. Jest to jedna $\mathrm{z}$ powszechnie stosowanych metod taksonomicznych, w której miarę agregatową oblicza się jako syntetyczny wskaźnik taksonomicznej odległości danego obiektu od teoretycznego wzorca rozwoju. Metoda wzorca rozwoju Hellwiga pozwala uporządkować zbiór obiektów (gmin) $\mathrm{P}_{\mathrm{i}}$ (gdzie: $\mathrm{i}=1$, $2, \ldots, n), \mathrm{z}$ których każdy jest opisany zbiorem $\mathrm{m}$ cech diagnostycznych, mających charakter stymulant lub destymulant.

Opis liczbowy zbioru obiektów można przedstawić w formie macierzy obserwacji X o postaci:

$$
X=\left[\begin{array}{cccc}
x_{11} & x_{12} & \ldots & x_{1 m} \\
x_{21} & x_{22} & \ldots & x_{2 m} \\
\ldots & \ldots & \ldots & \ldots \\
x_{n 1} & x_{n 2} & \ldots & x_{n m}
\end{array}\right]
$$

gdzie $x_{i j}$ - oznacza wartości j-tej cechy dla i-tego obiektu (i $\left.=1,2, \ldots, n ; j=1,2, \ldots, m\right)$.

$\mathrm{W}$ celu ujednolicenia zmiennych dokonuje się normalizacji cech przez ich standaryzację zgodnie ze wzorem:

$$
z_{i j}=\frac{x_{i j}-\bar{x}_{j}}{S_{j}} \quad(j=1,2 \ldots m)
$$

W efekcie przekształcenia otrzymano macierz standaryzowanych wartości cech Z:

\footnotetext{
${ }^{12}$ E. Nowak, Metody taksonomiczne w klasyfikacji obiektów społeczno-gospodarczych, PAN, Warszawa 1990, s. 143.
} 


$$
Z=\left[\begin{array}{cccc}
z_{11} & z_{12} & \ldots & z_{1 m} \\
z_{21} & z_{22} & \ldots & z_{2 m} \\
\ldots & \ldots & \ldots & \ldots \\
z_{n 1} & z_{n 2} & \ldots & z_{n m}
\end{array}\right]
$$

gdzie: $\mathrm{z}_{\mathrm{ij}}$ jest zestandaryzowaną wartością $\mathrm{x}_{\mathrm{ij}}$.

Ta macierz stanowiła podstawę do wyznaczenia wzorca rozwoju, czyli abstrakcyjnego obiektu (gminy) P0 o współrzędnych standaryzowanych $z_{01}, z_{02}, \ldots, z_{0 j}$, gdzie: $z_{0 j}=$ $\max \left\{z_{\mathrm{ij}}\right\}$, gdy $Z_{\mathrm{j}}$ jest stymulantą, oraz $\mathrm{z}_{0 \mathrm{j}}=\min \left\{\mathrm{z}_{\mathrm{ij}}\right\}$, gdy $\mathrm{Z}_{\mathrm{j}}$ jest destymulanta.

Wynika $\mathrm{z}$ tego, że wzorzec stanowi hipotetyczna gmina o najlepszych zaobserwowanych wartościach zmiennych. Następnie dla każdego obiektu $\mathrm{P}_{\mathrm{i}}$ (gminy) wyznaczono odległość od wzorca zgodnie z formułą:

$$
d_{i}=1-\frac{D_{i 0}}{D_{0}} \quad,(i=1,2 \ldots n)
$$

gdzie:

$$
D_{i 0}=\sqrt{\sum_{j=1}^{m}\left(z_{i j}-z_{0 j}\right)^{2}}
$$

(odległość i-tego obiektu od obiektu $\mathrm{P}_{0}$ )

$$
\begin{aligned}
& D_{0}=\bar{D}_{0}+2 S_{0} \\
& \bar{D}_{0}=n^{-1} \sum_{i=1}^{n} D_{i 0} \\
& S_{0}=\sqrt{n^{-1} \sum_{i=1}^{n}\left(D_{i 0}-\bar{D}_{0}\right)^{2}}
\end{aligned}
$$

W ten sposób wyznaczono wskaźniki syntetyczne dla każdej gminy. Miernik taksonomiczny $\mathrm{d}_{\mathrm{i}}$ przyjmuje wartości z przedziału $[0,1]$. Im bardziej wartości cech danej gminy są zbliżone do wzorca, tym poziom jej rozwoju jest wyższy, a im bardziej oddalone, tym niższy.

Do klasyfikacji gmin według poziomu rozwoju wykorzystano dwa parametry miernika taksonomicznego, czyli średnią arytmetyczną i odchylenie standardowe. Wyodrębniono następujące przedziały klasowe (grupy):

- klasa A (wyższy poziom rozwoju) - wartość miernika syntetycznego $d_{i}$ jest większa od średniej arytmetycznej cechy powiększonej o odchylenie standardowe (do tej klasy należą gminy, dla których odległość od wzorca przekracza wartość $\bar{d}_{i}+s_{d_{i}}$ ),

- klasa B (średni poziom rozwoju) $\bar{d}_{i}-s_{d_{i}}<d_{i} \leq \bar{d}_{i}+s_{d_{i}}$ (do tej klasy zaliczono gminy, dla których odległość od wzorca zawiera się w przedziale $\overline{\boldsymbol{Q}}_{i}-s_{d_{i}}, \bar{d}_{i}+s_{d_{i}}$-) 
- klasa C (niższy poziom rozwoju) $d_{i} \leq \bar{d}_{i}-s_{d_{i}}$ (do tej klasy należą gminy, dla których odległość od wzorca nie przekracza wartości $\left.\bar{d}_{i}-s_{d_{i}}\right)$, gdzie:

$d_{i}$ - wartość miernika syntetycznego obliczonego metodą wzorca rozwoju Hellwiga,

$\bar{d}_{i}$ - średnia arytmetyczna cechy (wskaźnika syntetycznego) $d_{i}$,

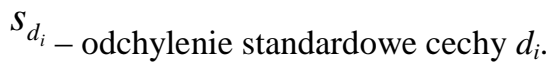

Obliczeń i analiz dokonano w programach Microsoft Office Excel 2003.

\section{ANALIZA POZIOMU ROZWOJU GMIN POWIATU RZESZOWSKIEGO}

W wyniku przeprowadzonych badań gminy powiatu rzeszowskiego ziemskiego zakwalifikowano pod względem ich poziomu rozwoju społeczno-gospodarczego do jednej z trzech klas A, B lub C. Dane zamieszczono w tabeli 2.

Tabela 2. Gminy powiatu rzeszowskiego ziemskiego w podziale na klasy rozwoju

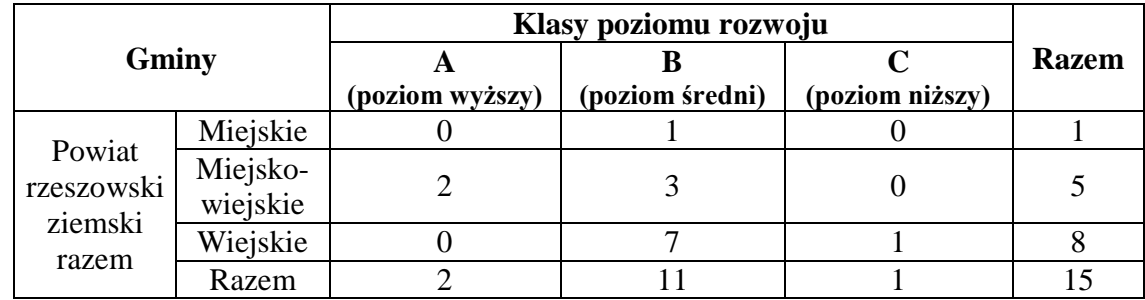

Źródło: opracowanie własne.

W klasie rozwoju A znalazły się gmina Boguchwała i gmina Tyczyn. Obie gminy mają status gmin miejsko-wiejskich. Wspólną cechą tych gmin jest bezpośrednie sąsiedztwo ze stolicą województwa podkarpackiego - Rzeszowem. Siedzibami obu wspomnianych gmin są miasta liczące niewiele ponad 5 tys. mieszkańców, mające znaczące w skali lokalnej tradycje przemysłowe. Infrastruktura gmin z klasy A ma charakter miejski, co przyczynia się zwiększenia szeroko rozumianej atrakcyjności inwestycyjnej. Warto zwrócić uwagę na to, że przez teren obu najwyżej sklasyfikowanych gmin przebiegają ważne szlaki komunikacyjne. W gminie Boguchwała jest to droga krajowa nr 9 Radom-Barwinek, natomiast przez gminę Tyczyn przebiega ważna droga wojewódzka nr 878 relacji Rzeszów-Dylągowka.

Do klasy rozwoju B zakwalifikowano aż 11 z 14 gmin powiatu rzeszowskiego ziemskiego. Wśród nich znalazła się jedyna gmina miejska - Dynów, 3 gminy miejskowiejskie (Głogów Małopolski, Sokołów Małopolski, Błażowa) oraz 7 gmin wiejskich (Krasne, Trzebownisko, Świlcza, Chmielnik, Kamień, Hyżne i Lubenia). W klasie C znalazła się gmina wiejska Dynów. Szczegółowy ranking gmin powiatu rzeszowskiego ziemskiego wraz $\mathrm{z}$ wartością miernika rozwoju zawarto $\mathrm{w}$ tabeli 3 . Na rysunku 1 przedstawiono administracyjny podział powiatu rzeszowskiego ziemskiego. 
Tabela 3. Ranking gmin powiatu rzeszowskiego ziemskiego według syntetycznego miernika rozwoju Hellwiga

\begin{tabular}{|c|c|c|c|}
\hline $\begin{array}{c}\text { Miejsce } \\
\text { w rankingu }\end{array}$ & Gmina & $\begin{array}{c}\text { Wartość miernika } \\
\text { rozwoju } \boldsymbol{d}_{\boldsymbol{i}}\end{array}$ & Klasa \\
\hline 1 & Boguchwała & 0,579 & $\mathrm{~A}$ \\
\hline 2 & Tyczyn & 0,563 & $\mathrm{~A}$ \\
\hline 3 & Krasne & 0,493 & $\mathrm{~B}$ \\
\hline 4 & Głogów Małopolski & 0,470 & $\mathrm{~B}$ \\
\hline 5 & Trzebownisko & 0,441 & $\mathrm{~B}$ \\
\hline 6 & Świlcza & 0,380 & $\mathrm{~B}$ \\
\hline 7 & Sokołów Małopolski & 0,340 & $\mathrm{~B}$ \\
\hline 8 & Chmielnik & 0,275 & $\mathrm{~B}$ \\
\hline 9 & Błażowa & 0,258 & $\mathrm{~B}$ \\
\hline 10 & Kamień & 0,246 & $\mathrm{~B}$ \\
\hline 11 & Dynów (gmina miejska) & 0,230 & $\mathrm{~B}$ \\
\hline 12 & Hyżne & 0,212 & $\mathrm{~B}$ \\
\hline 13 & Lubenia & 0,208 & $\mathrm{~B}$ \\
\hline 14 & Dynów (gmina wiejska) & 0,123 & $\mathrm{C}$ \\
\hline
\end{tabular}

Źródło: opracowanie własne.

Analizując dane zawarte $\mathrm{w}$ tabeli 3 oraz na rysunku 1, należy zauważyć, że gminy przylegające do miasta Rzeszów charakteryzują się wyższym poziomem rozwoju społeczno-gospodarczego $\mathrm{w}$ porównaniu $\mathrm{z}$ innymi gminami powiatu rzeszowskiego ziemskiego. Następuje tu zjawisko ,rozlewania” się rozwoju z ośrodka centralnego w województwie podkarpackim, jakim jest jego stolica - Rzeszów. Gminy okalające swoistym pierścieniem Rzeszów charakteryzują się stosunkowo dobrym wyposażeniem w infrastrukturę techniczną i społeczną. Obszary te są również dość dobrze skomunikowane z Rzeszowem systemem transportu publicznego, co powoduje, że mieszkańcy podrzeszowskich gmin mogą korzystać z usług oferowanych przez stolicę regionu. Wspomniane czynniki powodują, że gminy takie jak Boguchwała, Tyczyn, Krasne, Głogów Młp., Trzebownisko czy Świlcza są atrakcyjne zarówno dla mieszkańców, potencjalnych mieszkańców, jak również dla inwestorów. Liczba mieszkańców (zwłaszcza tych pracujących), liczba podmiotów gospodarczych, rodzaj gruntów i nieruchomości to czynniki, które znacząco wpływają na wzrost dochodów budżetowych jednostek samorządu terytorialnego, co w konsekwencji pozwala na realizację inwestycji czy dostarczanie usług komunalnych podnoszących jakość życia społeczności lokalnych. Warto zwrócić uwagę na kanały rozprzestrzeniania się rozwoju od miejsca centralnego, jakim jest Rzeszów, na peryferie. Miejsca zajmowane w rankingu przez poszczególne gminy wskazują, że poziom rozwoju nie jest odwrotnie skorelowany z odległością gminy od Rzeszowa. Okazuje się bowiem, że najbardziej oddalona od Rzeszowa gmina Kamień charakteryzuje się wyższym syntetycznym wskaźnikiem rozwoju od gminy Lubenia. Wynika to z tego, że gmina Kamień położona jest wzdłuż drogi krajowej nr 19 łączącej Rzeszów z Lublinem i dalej Białymstokiem. 
Rys. 1. Administracyjny podział powiatu rzeszowskiego ziemskiego

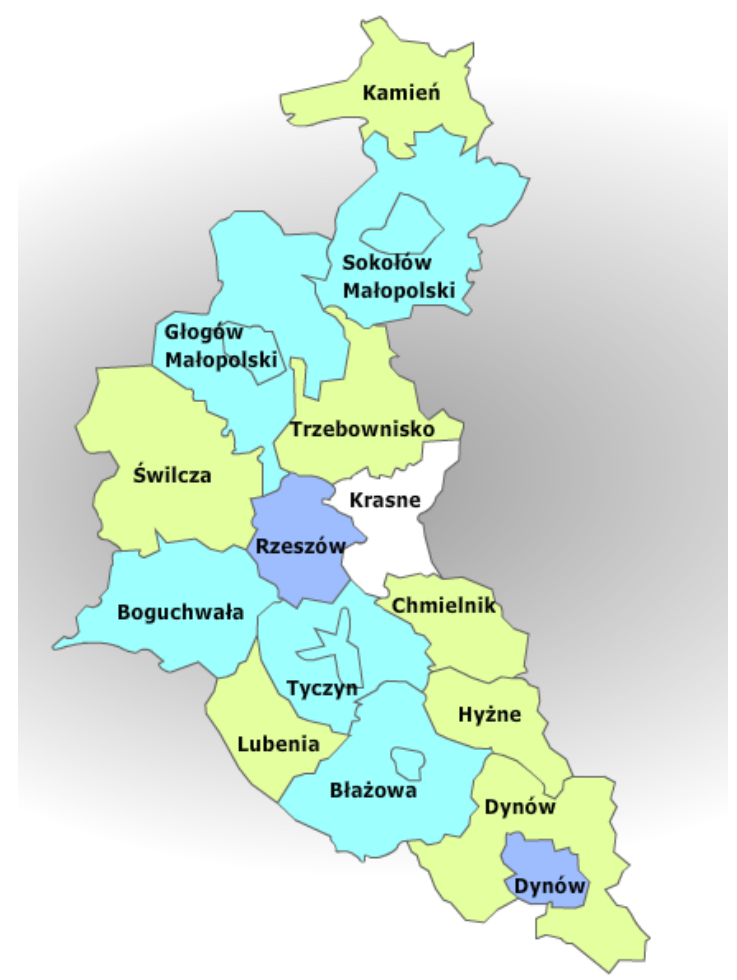

Źródło: http://administracja.mac.gov.pl/

Gmina Lubenia pozbawiona jest niewątpliwego atutu posiadania na swoim terenie znaczącego ciągu komunikacyjnego. Dowodzi to jednoznacznie, że proces ,rozlewania się" rozwoju odbywa się poprzez układ komunikacyjny, tak więc sieć dróg stanowi ważny element rozprzestrzeniania się rozwoju z miejsc centralnych na peryferia.

\section{PODSUMOWANIE}

Dane zawarte w tabeli 3 wskazują na znaczne zróżnicowanie w poziomie rozwoju gmin powiatu rzeszowskiego ziemskiego. Najlepiej rozwinięte okazały się gminy miejsko-wiejskie usytuowane w bezpośrednim sąsiedztwie Rzeszowa. Zidentyfikowano ogólną zależność, zgodnie z którą poziom rozwoju gmin powiatu rzeszowskiego ziemskiego maleje wraz ze wzrostem odległości od Rzeszowa. Istotną rolę dla rozwoju społeczno-gospodarczego odgrywa również skomunikowanie gmin. Gminy, przez których teren przebiegają szlaki komunikacyjne o charakterze ponadlokalnym czy ponadregionalnym, osiagnęły wyższy poziom rozwoju. Ważne znaczenie ma również trafna identyfikacja potencjału rozwojowego poszczególnych gmin powiatu rzeszowskiego. W powiecie rzeszowskim można zauważyć istotne różnice pod względem tego potencjału. Na obszarze badanego powiatu istnieje znaczne zróżnicowanie pod względem ukształtowania terenu, zagospodarowania przestrzennego, wyposażenia 
infrastrukturalnego, tradycji, kultury czy lokalnych zwyczajów. W tak różnych warunkach poszczególne gminy powinny realizować odmienne strategie rozwoju. Dość powszechne jest jednak w samorządach przedkładanie zarządzania bieżącego nad konsekwentne wdrażanie właściwie opracowanej strategii rozwoju. Wydaje się, że jest to jeden $\mathrm{z}$ ważnych czynników powodujących znaczne zróżnicowanie poziomu rozwoju na niewielkim obszarze powiatu rzeszowskiego ziemskiego. Problem ten jednak wybiega poza ramy niniejszego opracowania i stanowić może przyczynek do dalszych badań.

\section{LITERATURA}

[1] Borkowski B., Dudek H., Szczęsny W., Ekonometria, wybrane zagadnienia. Wydawnictwo Naukowe PWN, Warszawa 2004.

[2] Kosiedowski W., Zarzadzanie rozwojem regionalnym i lokalnym, [w:] Gospodarka regionalna i lokalna, red. Z. Strzelecki, PWN, Warszawa 2008.

[3] Markowski T., Teoretyczne podstawy rozwoju lokalnego i regionalnego, [w:], Gospodarka regionalna i lokalna, red. Z. Strzelecki Warszawa 2008.

[4] Nowa encyklopedia powszechna PWN, Warszawa 1997.

[5] Nowak E., Metody taksonomiczne $w$ klasyfikacji obiektów społecznogospodarczych, PAN, Warszawa 1990.

[6] Starzyńska W., Statystyka praktyczna, Wydawnictwo Naukowe PWN, Warszawa 2005.

[7] Taksonomiczna analiza przestrzennego zróżnicowania poziomu życia $w$ Polsce $w$ ujęciu dynamicznym, red. A. Zeliaś, Wydawnictwo Akademii Ekonomicznej w Krakowie, Kraków 2000.

[8] Ziółkowski M., Goleń M., Zarzqdzanie strategiczne rozwojem lokalnym, [w:] Zarzqdzanie gospodarka i finansami gmin, red. H. Suchocka-Krysiak, Warszawa 2003.

\section{DEVELOPMENT LEVEL RATING OF RZESZÓW DISTRICT COMMUNES (WITH HELLWIG METOD)}

The study addresses the issue of local development and factors determining this development. The main purpose of the paper is to determine the socio-economic development level of Rzeszów district communes. The method used (in this paper) is Hellwig synthetic development measure. This method takes into account a number of indicators of an economic, social, technical, technological and ecological character. Among them, should be noted: the birthrate indicator, the percentage of employed people in the total population, migration balance in persons per 1000 inhabitants, the share of the unemployed in the working-age population, communal roads with hard surfaces in $\mathrm{km}$ per $100 \mathrm{~km}^{2}$, water supplies in $\mathrm{km}$ per $100 \mathrm{~km}^{2}$, the percentage of the population using the sewage farm in the population in total, the own communes income per capita, communes financial and investment expenditures per capita, registered in REGON private economic subjects per 1000 inhabitants, the percentage of high educated councilors. Studies have static character and the collected empirical data represent the state at the date of 31 December 2011. Conducted research has shown significant development diversity of surveyed communes. As the major indicators of development were considered: distance to central place, which in this case is Rzeszów and communication system availability. An important problem is also diversification at communes development potential. In the view of conducted research found that 
the most developed communes of Rzeszów District are Boguchwała and Tyczyn, and the least developed is the rural commune - Dynów.

Keywords: local development, Hellwig metod, Rzeszów rural district

DOI:10.7862/rz.2013.hss.15

Tekst złożono w redakcji: maj 2013

Przyjęto do druku: wrzesień 2013 